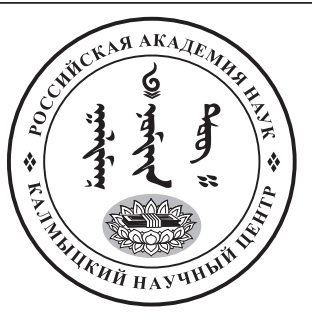

Published in the Russian Federation

Oriental Studies (Previous Name: Bulletin of the Kalmyk Institute

for Humanities of the Russian Academy of Sciences)

Has been issued as a journal since 2008

ISSN: 2619-0990; E-ISSN: 2619-1008

Vol. 13, Is. 3, pp. 790-803, 2020

DOI: $10.22162 / 2619-0990-2020-49-3-790-803$

Journal homepage: https://kigiran.elpub.ru

УДК 398.61

DOI: 10.22162/2619-0990-2020-49-3-790-803

\title{
О народно-бытовой традиции загадывания загадок у донских калмыков (по материалам И. И. Попова)
}

\section{Саглара Викторовна Мирзаева}

${ }^{1}$ Калмыцкий научный центр Российской академии наук (д. 8, ул. И. К. Илишкина, 358000 Элиста, Российская Федерация)

научный сотрудник

iD 0000-0002-8542-0260. E-mail: saglaramirzaeva@kigiran.com

(C) КалмНЦ РАН, 2020

(C) Мирзаева С. В., 2020

Аннотация. Цель статьи - описание бытового фона функционирования загадок среди донских калмыков конца XIX в. по материалам известного собирателя калмыцкого фольклора И. И. Попова. Материалы. Одна из девяти рукописных тетрадей, составляющих его научное наследие и лишь частично введенных в научный оборот, посвящена загадкам и, помимо фольклорных текстов на «ясном письме» и в переводе на русский язык, включает предисловие автора, в котором он дает краткую характеристику этого жанра и воссоздает игровую ситуацию, наглядно демонстрирующую функционирование загадок в народной среде. Результаты. Мы предполагаем, что при написании предисловия И. И. Попов опирался на труд М. А. Кастрена «Опыт перевода бурятского языка», шестнадцать загадок из которого он включил в свою работу, поскольку финский монголовед приводит аналогичные сведения по селенгинским бурятам. По описанию И. И. Попова, игра в загадки у калмыцких детей командная, из индивидуальных участников исследователь выделяет двух толгачи — руководителей партий, на которые делятся участники, и туульчи - знатока загадок, которого стремится заполучить к себе каждая из партий. Важный элемент игры составляет осмеяние проигравших, которое встречается у многих народов как одна из форм наказания. Исследователь приводит пример игры, в ходе которой партии задают друг другу числовые загадки, относящиеся к первому десятку чисел. Сравнение с традициями других тюрко-монгольских народов, а именно бурят и алтайцев, показывает, что калмыцкая традиция бытования загадок имеет как схожие черты (связь с зимним периодом, наказание как обязательный элемент игры), так и свои особенности. В первую очередь у калмыков и бурят это коллективная игра, в то время как у алтайцев участники могут не объединяться в команды, а играть индивидуально. Второе важное отличие заключается в возрастных категориях участников игры: у калмыков это дети, у бурят — молодые супружеские пары, а у алтайцев - старшие по возрасту люди. В приложении приводится факсимиле предисловия И. И. Попова к труду «Загадки донских калмыков».

Ключевые слова: загадки, донские калмыки, И. И. Попов, инедиты, бытовой фон 
Благодарность. Исследование выполнено при финансовой поддержке РФФИ в рамках научного проекта № 20-012-00287 «Инедиты калмыцкого фольклора из архива И. И. Попова». Для цитирования: Мирзаева С. В. О народно-бытовой традиции загадывания загадок у донских калмыков (по материалам И. И. Попова) // Oriental Studies. 2020. Т. 13. № 3. С. 790803. DOI: $10.22162 / 2619-0990-2020-49-3-790-803$

UDC 398.61

DOI: $10.22162 / 2619-0990-2020-49-3-790-803$

\title{
Don Kalmyks: the Folk Tradition of Riddle-Telling Revisited (a Case Study of I. Popov's Materials)
}

\author{
Saglara V. Mirzaeva ${ }^{1}$ \\ ${ }^{1}$ Kalmyk Scientific Center of the RAS (8, Ilishkin St., Elista 358000, Russian Federation) \\ Research Associate \\ iD 0000-0002-8542-0260. E-mail: saglaramirzaeva@kigiran.com
}

(C) KalmSC RAS, 2020

(C) Mirzaeva S. V., 2020

\begin{abstract}
Goals. The article aims to describe common riddle-telling patterns of the Don Kalmyks as of the late $19^{\text {th }}$ century traced in works by I. Popov, a famous collector of Kalmyk folklore samples. Materials. One of the nine handwritten books constituting his academic heritage which is only partially introduced to researchers is titled 'Riddles of the Don Kalmyks'. It includes 367 Clear Script texts accompanied by Russian translations and the author's foreword which provides a brief description of the genre and reconstructs standard game situations explicitly demonstrating the functioning of riddles in the folk tradition. Results. Our hypothesis is that here I. Popov was following M. Castrén's 'Attempted Essay on the Buryat Language' (sixteen riddles from the latter included in Popov's book) because the ethnologist gives similar information on the Selenga Buryats. Results. According to I. Popov's description, riddle-telling among Kalmyk children was a team game. As for individual players, there were tolgachi, i.e. leaders of two teams participants were divided into, and tuulchi - a master of riddles highly esteemed by other players. An important component of the game is mockery of losers, which can be found in many cultures as a form of punishment. I. Popov gives an example of one game where two teams ask numerical riddles (related to figures from one to ten) to each other. Comparison with traditions of other Turko-Mongols, such as Buryats and Altaians, shows that the Kalmyk tradition of riddle-telling shares similar features, e.g. connection of riddle-telling with the winter period, punishment as a compulsory element of the game. Still, it has some specific features. Firstly, for Kalmyks and Buryats this is a collective game, while in the Altaian tradition participants can play individually. The second important distinctive feature is the difference of age categories of players: in the Kalmyk tradition those are children, in the Buryat - young married couples, and in the Altaian — adults. The Appendix provides a facsimile of the I. Popov's foreword to his 'Riddles of the Don Kalmyks'.
\end{abstract}

Keywords: riddles, Don Kalmyks, I. Popov, inédites, folk tradition

Acknowledgments. The reported study was funded by RFBR, project no. 20-012-00287 'Inédites of Kalmyk Folklore from I. Popov's Archives'.

For citation: Mirzaeva S. V. Don Kalmyks: the Folk Tradition of Riddle-Telling Revisited (a Case Study of I. Popov's Materials). Oriental Studies. 2020. Vol. 13(3): 790-803. (In Russ.). DOI: 10.22162/2619-0990-2020-49-3-790-803 


\section{Введение}

Одним из известных собирателей калмыцкого фольклора, чей вклад в сохранение культурного наследия калмыков сложно переоценить, можно назвать И. И. Попова. В его записях, сохранившихся в виде девяти рукописных книг, представлен богатейший материал по эпосу, сказкам, преданиям и другим видам народного творчества калмыков. О самом исследователе известно лишь, что он закончил Санкт-Петербургский и Лейпцигский университеты и в конце XIX в. поселился на Дону, в балке Средняя Аюла, где и занимался изучением и фиксацией культуры донских калмыков вплоть до своей кончины (приблизительно в середине 20-х гг. XX в. ${ }^{1}$ ) [Алексеева 2010: 77-79].

Анализ его материалов позволяет утверждать, что он в совершенстве владел как ойратским «ясным письмом», так и разговорным калмыцким языком, а также обладал широким исследовательским кругозором и доступом к академическим трудам по востоковедению. Тем не менее большая часть его трудов до сих пор не опубликована: в качестве исключения можно назвать исследовательскую статью Д. В. Убушиевой, в которой были введены в оборот образцы кумулятивных сказок, записанные И. И. Поповым [Убушиева 2017].

В рамках исследовательского проекта «Инедиты калмыцкого фольклора из архива И. И. Попова» мы планируем ввести в научный оборот записанные им образцы фольклора донских калмыков, в частности загадки, составляющие одну из тетрадей. Цель данной статьи - дать описание бытового фона функционирования загадок у донских калмыков конца XIX в. по материалам И. И. Попова.

\section{Материалы}

Состоящая из шестидесяти девяти листов, тетрадь озаглавлена как «Загадки донских калмыков²» (ойр. Buzabai

${ }^{1}$ Во вступительной части к изданию записанного И. И. Поповым «Джангара» 1940 г. В. А. Закруткин пишет, что он умер «лет пятнадцать тому назад» [Калмыцкий эпос 1940: 254].

2 В оригинальном написании - «Загадки донских калмык». xalimayuudiyin tayilyatai tuulisiyin bičiq $)^{3}$ и датирована 1892 г. [ГАРО].

Тексты трехсот шестидесяти семи загадок приводятся в написании на «ясном письме» и переложении на современный автору калмыцкий язык и сопровождаются переводом на русский язык. В данной статье мы анализируем предисловие автора, содержащее интересные сведения о бытовом фоне загадывания загадок, который зачастую остается вне поля зрения фольклористов. Вначале приведем его краткую характеристику. Предисловие, объем которого составляет 6 страниц рукописного текста по 27-28 строк на странице ${ }^{4}$, начинается с краткого определения загадки как одной из игр, распространенных среди калмыцкой молодежи. Далее И. И. Попов дает описание ее основных правил и конкретной игровой ситуации, когда участники делятся на две группы и состязаются в загадывании загадок. Листы 4-6 рукописи содержат рассуждения автора об этом жанре как особой форме поэтического творчества народа, специфике калмыцкой загадки и ее образной системы. В конце И. И. Попов отмечает отсутствие литературы по этому жанру ввиду нежелания калмыков записывать произведения своей национальной поэзии, тем самым обосновывая актуальность своего труда. Завершается предисловие указанием даты и места его составления - 29 марта 1892 г. (Вербное воскресенье), Балка Средняя Аюла.

\section{О некоторых особенностях загадок}

Загадки представляют собой «международный», т. е. общий для многих культурных традиций, жанр фольклора. Различные аспекты этого жанра на калмыцком

${ }^{3}$ На титульном листе также указано: «В подлинном тексте и перевод. Собрал и записал И. И. Попов» (ойр. ivan ivanoviči popov bičibei bi).

4 Пагинация страниц двойная: нумерация страниц с использованием римских цифр проставлена, вероятно, автором в верхней части листа по центру; кроме того, в верхнем правом углу представлена сквозная нумерация, относящаяся ко всей тетради и проставленная арабскими цифрами. 
материале рассматривались в публикациях И. С. Устиевой [Устиева 2010], Т. Г. Басанговой (Борджановой) и А. А. Бурыкина [Басангова 2009; Бурыкин, Басангова 2009], Ц. Б. Селеевой [Селеева 2013] и др.

Многие исследователи сходятся во мнении, что на раннем этапе своего развития загадка была тесно связана с ритуалом ${ }^{5}$, но впоследствии эта связь была утрачена и загадка перешла в игровой фольклор. Н. А. Лавонен пишет, что загадка имеет двухчастную структуру - саму загадку и отгадку, которые не могут существовать по отдельности 6 [Лавонен 1977: 84].

В калмыцком названии жанра загадки также присутствует указание на ее двукомпонентность: тәәлһәтә (тәәлвртә) тууль букв. 'сказка с пояснением'. Термин сказка в данном случае, по нашему мнению, подтверждает связь этих двух жанров, обнаруживаемую во многих фольклорных традициях мира [Лавонен 1977: 22]. И. И. Попов считает, что второй компонент тууль в значении 'сказка, басня' свидетельствует о том, что «калмыки и смотрят на загадку именно как на поэтическое произведение» [ГАРО. Ф. 55. Оп. 1. Л. 5].

Калмыцкая загадка имеет в первую очередь педагогическую и развлекательную функции, однако в ней сохранились и реликты производственно-магической и обрядовой функций, что подтверждается данными об игровом процессе загадывания загадок, приводимыми И. И. Поповым в предисловии. Автор начинает описание следующим образом: «Загадки, называемые по-калмыцки тайльгатай (по выговору тэльгэтэ) туулис, т. е. сказки (смысл которых надо разузнать), - есть одна из игр калмыцкой молодежи. Мальчики и девочки собираются, преимущественно в зимнее время, в одну кибитку, разделяются на две партии и начинают предлагать друг другу загадки» [ГАРО. Ф. 55. Оп. 1. Л. 2].

${ }^{5}$ В этой связи интересно отметить, что загадка (дэу) в широком смысле как тайный, символический, язык была одним из символов государственности у древних тибетцев (см.: [Намкай Норбу 1997]).

${ }^{6}$ В фольклоре монгольских народов числовые загадки при разрушении структуры (т. е. без отгадки) могут продолжать свое функционирование в афористической поэзии в виде трех- и четырехстиший.
Н. П. Дыренкова и В. П. Худяков указывают, что у шорцев и бурят загадки загадываются зимой [Дыренкова 1940: Х; цит. по: Лавонен 1977: 17]. Связь с зимним периодом можно расценить как архаический элемент древней магии.

Порядок игры с загадыванием загадок в описании И. И. Попова

Вначале дети выбирают руководителей двух партий - толгачи (ойр. toloyoyiči) - из старших, если же все участники одного возраста, то толгачи выбираются по желанию. Их обязанность, в первую очередь, заключается в том, чтобы «разделить играющих на две партии и подобрать в состав каждой партии играющих так, чтобы не было споров». Если при разделении остается один лишний участник, толгачи состязаются друг с другом на пряжке, бечевке или палке. Участник попадает в ту группу, руководитель которой побеждает в соревновании. Таким же способом выбираются в ту или иную группу участники, называемые туульчи, или мастера загадывать загадки, которые очень ценятся в этой игре ${ }^{7}$. После формирования двух групп, или, как их называет И. И. Попов, партий начинается игра, очередность в которой также определяют толгачи с помощью состязания. Загадывает загадку любой из участников, включая руководителя, если желающих несколько, порядок загадывающих определяет толгачи. Если партия В не может отгадать загадку, она начинает сама предлагать загадки до тех пор, пока партия А не окажется в таком же положении, т. е. не сможет отгадать предложенную загадку. В таком случае партия В спрашивает разгадку прежде не отгаданной загадки, партия А дает ответ и снова начинает предлагать загадки, пока их запас не иссякнет. Максимальное количество ответов, которые может дать партия, - три: если загадка отгадана с четвертой попытки, ответ не принимается в расчет.

И. И. Попов дает реконструкцию игровой ситуации, в которой одиннадцать детей

${ }^{7}$ И. И. Попов отмечает, что калмыки, считая загадывание загадок одной из форм творческой деятельности, «ценят больше того, кто умеет составлять загадки, а не разрешать их». 
делятся на две группы по пять и шесть человек соответственно и загадывают числовые загадки. Приведем описание ниже ${ }^{8}$.

Итак, приведем пример игры: играющих собралось одиннадцать человек: 1) Кўгўльчэ; 2) Бӣвэ; 3) Му̀шка; 4) Сангаджи; 5) Шарко; 6) Дорджи; 7) Лиджи; 8) Пу̀тя; 9) Унджу; 10) Аюда; 11) Нану. Толгачи первой партии, состоящей из шести человек, - Кўгўльчэ, толгачи второй из остальных пяти - Лиджи. (нрзб.) Начинает партия Лиджи: «Нэгинь - ола» ${ }^{9},-$ предлагает вопросы она. «Нэг юзсюнь кўгэн тавтий-чи ${ }^{10}$ » (т. е. вопрос: один - разгадай — ответ: разве не угадают раз виденного человека). Партия Кўгўльчи следовательно отгадала. (нрзб.) Тогда партия Лиджи снова спрашивает: «Хојир» ${ }^{11}$ (два). Партия Кўгўльчи отвечает: «Хојир гартан бэрьсэн тавхичи?» ${ }^{12}$ (Разве упустит то, что держит обеими руками). Снова партия Лиджи говорит: «Гурвун» ${ }^{13}$ (три). Партия Кўгўльчи не может отгадать. Тогда начинает спрашивать уже партия Кўгўльчи: «Дӧрвӧн» ${ }^{14}$ (четыре). Партия Лиджи отвечает: «Юкуурин дӧрвӧн кӧкӧл» ${ }^{15}$ (Четыре соска у коровы). Партия Кўгўльчи снова спрашивает: «Тавун» ${ }^{16}$. Партия Лиджи отвечает: «Гарин тавун хургун» ${ }^{17}$ (Пять пальцев на руке). Партия Кўгўльчи спрашивает: «Зурган» ${ }^{18}$ (шесть). Партия Лиджи не знает отгадки. Тогда его партия должна сказать отгадку на «гурбан» (три), которую не знала партия Кўгўльчи «Гурван кӧлини чидырлесэн мӧрин ха̄ран одхувинэ?» ${ }^{19}$ (Куда уйдет конь, у которого спутаны три ноги). А дальше снова начинает давать загадки партия Кўгўльчи: «Долан» (семь). Партия Кўгульчи говорит: «Одон долон бурхан» ${ }^{20}$ (Семь звезд Большой Медведицы). Партия Лиджи продолжает: «Найман» (восемь). Партия Кўгўльчи говорит: «Найман кӧкӧдэ ӧлӧгчин кичигўдэн эсэ

8 Текст оформлен согласно правилам современной орфографии и пунктуации. В сносках к калмыцким фразам, приводимым И. И. Поповым, дается современное калмыцкое написание.

${ }^{9}$ Негнь ол.

${ }^{10}$ Нег Узсн күҮһан тәвхийч?

${ }^{11}$ Xойр.

${ }^{12}$ Хойр һартан бәрсән тәвхийч?

${ }^{13}$ Һурвн.

${ }_{14}^{14}$ Дөрвн.

${ }^{15}$ Үкрин дөрвн көкл.

${ }^{16}$ Тавн.

${ }^{17}$ Һарин тавн хурһн.

18 Зурһан.

${ }^{19}$ Һурвн көлнь чөдрлсн мөрн хама одхвинь?

${ }^{20}$ Одн долан бурхн. тэджэджи чадху-вий?» ${ }^{21}$ (Разве не может прокормить своих щенят сучка, когда у ней 8 сосков). Партия Лиджи спрашивает: «Јэсўн» 22 (девять). Партия Кўгўльчи не знает отгадки. Партия Лиджи спрашивает отгадку «зурган» (шести) «Зурган юкюрян саасан эмэгэн ӧвӧгӧн хојор айрак чигэ эсэ кэджи ўджи чадху билю?» ${ }^{23}$ (Разве не могут сделать и пить вдоволь айраку и кумысу бабка и дед, которые доят шесть коров). Дальше же партия Кўгўльчи не знает загадки. Тогда толгачи партии Лиджи говорит: «Шулугар кэлэ, эсэ кэлэхлэ-чинь, чамайги ја̄ндагална̄ва» ${ }^{24}$ (Говори скорей, если не скажешь, я назначу над тобой посмеяние). Партия Кўгўльчи все-таки не говорит новой загадки. Тогда толгачи Лиджи начинает спрашивать у кого-либо из своей партии, например Пу̀тя: «Јандак јундак југини абунай-чи?» 25 (Јандак, јундак, что возьмешь). Пу̀тя отвечает: «Толгайни авна-ва» ${ }^{26}$ (Возьму голову). Лиджи: «Тэрююгээр йу кэнээ-чи?» ${ }^{27}$ (Что с ней будешь делать). «Ша̄вур кэнэ-вэ» ${ }^{28},-$ говорит Пу̀ти. Лиджи: «Ша̄вра̄p юу кэнэ-чи?» ${ }^{29}$ (Что будешь делать той колотушкой). Пути отвечает: «Гаса цокна-ви» ${ }^{30}$ (Забью прикол). Тогда толгачи Лиджи спрашивает у другого члена своей партии, например, Унджу: «Јандак јундак југини абунай-чи» ${ }^{31}$ (Что возьмешь?). Унджу: «Гариини авна-ва» ${ }^{32}$ (Возьму руки). Лиджи: «Гараарэн юу кэнэ-чи?» ${ }^{33}$ (Что будешь делать с руками). Унджу: «Гаса кэнэ-ви» ${ }^{34}$ (Сделаю прикол). Лиджи: «Гасаар юу кэнэ-чи?» ${ }^{35}$ (Что будешь делать с этим приколом). «Гэрдэн чикидху (нрзб.) авна-ви» ${ }^{36}$ (Привяжу к нему арканами кибитку [во время сильного ветра]). Затем толгачи Лиджи спрашивает у третьего члена своей партии, например Аюды: «Јандак јундак југини авна-чи?» ${ }^{37}$

${ }^{21}$ Наวмн көкта өлгчн кичгүдан эс тежсәж, чадхви?

${ }_{22}$ Йисн.

23 Зурһан үкрән саасн эмгн өвгн хойр әәрг чигә эс кеж уужс чадх билү?

${ }^{24}$ Шулуһар кел, эс келхләчнь, чамаг яндглнав.

${ }^{25}$ Яндг юндг юуһинь авнач?

${ }^{26}$ Толиань авнав.

${ }^{27}$ Теруһәр ю кенәч?

${ }^{28}$ Шаавр кенәв.

${ }^{29}$ Шааврар ю кендч?

${ }^{30}$ һас ичокнав.

${ }^{31}$ Яндг юндг юуһинь авнач?

${ }^{32}$ Һаринь авнав.

${ }^{33}$ Һарарн ю кендч?

${ }^{34}$ һас кенәв.

${ }^{35}$ Һасар ю кендч?

${ }^{36}$ Гертән чикдх (нрзб.) авнав.

37 Яндг юндг юуһинь авнач? 
(Что возьмешь). Аюда: «Кӧлини авна-ви» ${ }^{38}$ (Возьму его ноги). Лиджи: «Кӧлээрэн юу кэнэ-чи?»» (Что будешь делать с его ногами). Аюда: «Кӧшу̀

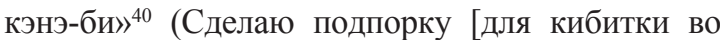
время ветра]). Лиджи: «Кӧшу̀гээр юу кэнэ-чи?»» (Что будешь делать с подпоркой). Аюда: «Гэрэн салькин бойхолайги тулна-би» ${ }^{42}$ (Когда будет ветер, подопру кибитку) и так дальше по числу играющих [ГАРО. Ф. 55. Оп. 1. Л. 3-4].

\section{Обсуждение}

В игровой ситуации, описываемой И. И. Поповым, участники загадывают друг другу так называемые «числовые» загадки, «суть которых заключается в умении выявить содержание чисел от одного до десяти» [Селеева 2013: 72]. Эти загадки также составляют основу другого вида устного творчества монгольских народов, характеризуемого А. В. Бурдуковым как состязание в мудрости между подростками, носившее дидактический характер (цит. по: [Селеева 2013: 72]) ${ }^{43}$. Загадки из предисловия И. И. Попова относятся к первому десятку чисел (от единицы до восьми). В целом они соотносятся с аналогичными монголоязычными образцами, подробно рассмотренными в статье Ц. Б. Селеевой [Селеева 2013], однако имеют свои особенности:

1. Нег 'один'. Нег Үзсн күүһән тәвхийч? 'Разве не угадают раз виденного человека?'

2. Хойр 'два'. Хойр һартан бәрсән mәвхийч? 'Разве упустит то, что держит обеими руками?'

3. Һурвн 'три'. Һурвн көлнь чөдрлсн мөрн хама одхвинь? 'Куда уйдет конь, у которого спутаны три ноги?'

4. Дөрвн 'четыре'. Үкрин дөрвн көкл 'Четыре соска у коровы'.

5. Тавн 'Пять'. Һарин тавн хурһн 'Пять пальцев на руке'.

6. Зурһан 'шесть'. Зурһан Үкрән саасн эмгн өвгн хойр дәрг чигә эс кежс уужс чадx билу? 'Разве не могут сделать и пить вдоволь айраку и кумысу бабка и

\footnotetext{
${ }^{38}$ Көлинь авнав.

${ }^{39}$ Көләрнь ю кенәч?

${ }^{40}$ Көша кенав.

${ }^{41}$ Көшәһәр ю кенәч?

42 Герән салькн болхлаг тулнав.

${ }^{43}$ Интересно отметить, что аналогичные загадки-вопросы в традиции финно-угорских народов использовались в процессе гадания [Лаво-
} нен 1977: 25]. дед, которые доят шесть коров?'

7. Долан 'семь'. Одн долан бурхн 'Семь звезд Большой Медведицы'.

8. Нәамн 'восемь'. Нәамн көктә өлгчн кичгүддн эс тэжсзљс чадхви 'Разве не может прокормить своих щенят сучка, когда у ней восемь сосков?'

Анализ этнографических данных по древнему сезонному календарю монгольских народов позволяет предположить, что в поджанре числовых загадок сохранилась архаичная система счета зимнего времени по «девятидневкам» [Бакаева 2016]. Таким образом, процесс игры в загадки (борьба коллективов / борьба природных сил) можно интепретировать как символический акт «преодоления» тяжелого периода времени через девятеричный счет.

Важным элементом игры, в которой также можно усмотреть пережиток ранней обрядовой функции загадки, является описываемое И. И. Поповым высмеивание проигравших: «... есть уже одна загадка, не разгаданная ей, то противная партия начинает посмеиваться над ней за то, во-первых, что она не отгадала загадки, и за то, во-вторых, что не может предложить загадки» [ГАРО. Ф. 55. Оп. 1. Л. 2об-3]. Как пишет Н. А. Лавонен, осмеяние было одной из древних и сильных форм общественного осуждения, в данном случае - наказания за неумение отгадывать [Лавонен 1977: 33]. И. И. Попов называет осмеяние јангак и указывает, что побежденные осмеиваются «за свою неспособность, за свою посредственность, за то, что они не поэты, а такие же люди, как и все» [ГАРО. Ф. 55. Оп. 1. Л. 5].

В рамках данной статьи также представляется интересным привести аналогичное описание игрового процесса загадывания загадок у селенгинских бурят середины XIX в., содержащееся в труде финского лингвиста и этнографа М. А. Кастрена «Опыт грамматики бурятского языка» (нем. Versuch Einer Burjätischen Sprachlehre) $(1857 \text { г. })^{44}$ [Castren 1857], поскольку И. И. Попов ссылается на него. Он указывает в тетради, что получил эту книгу в 1900 г., и приводит шестнадцать загадок из

44 Шестьдесят загадок селенгинских бурят были записаны со слов Галсана Гомбоева. О вкладе М. А. Кастрена в монголоведение см.: [Жаргалова 2016]. 
нее. Можно предположить, что И. И. Попов включил информацию по бытовому фону загадывания загадок в предисловие, ориентируясь на труд М. А. Кастрена.

Итак, ученый пишет, что у забайкальских бурят существует традиция, когда молодые супружеские пары собираются вместе зимними вечерами и играют в загадки. Загадывание в любой другой период, кроме зимы, строго табуировано: как указывает М. А. Кастрен, нарушение этого запрета может привести к выкидышам или рождению увечного потомства у крупного рогатого скота. Присутствующие делятся поровну на две группы, независимо от пола, и договариваются, сколько попыток дается на отгадку ответа. Если одна из групп не может разгадать предложенную загадку, она вынуждена уступить одного из своих участников другой группе, которая также получает право снова загадать загадку. Далее победившая группа предлагает соперникам «выкупить» своего участника с помощью специальных стихотворных прибауток [Castren 1857: 228-229].

«Продажа» участника, подробно описанная К. Е. Укачиной на материале алтайского фольклора [Укачина 1984: 22], очевидно, является наказанием за неотгадывание загадки. В традиции донских калмыков эту функцию, по описанию И. И. Попова, выполняло осмеяние, которое по структуре аналогично «продаже» участника проигравшей стороны соперникам. Ведущий победившей стороны задает своим участникам вопросы о том, что (какую часть тела) они готовы взять и что будут с ней делать: например, диалог Лиджи и Пу̀ти:

— Яндак, юндак, что возьмешь?

— Возьму голову

— Что с ней будешь делать?

- Сделаю колотушку.

— Что будешь делать той колотушкой?

- Забью прикол.

К. Е. Укачина приводит пример игры у алтайцев, в которой концепция «продажи» проигравшего получила развитие таким образом, что его «продают» старикам, лентяям или неполноценным в жизни людям:

- Дьядан (дедушка)! Что Вам нужно? Для воротника рыжую лисицу или возьмете неразгадавшую загадку краснощекую Дьалку? Старик, постукивая посохом, говорит:
- Зачем мне, старику, рыжую лисицу для воротника? Возьму-ка краснощекую Дьалку. Из головы ее сделаю котел, из глаз - чугун, из ушей - «туткуш» (держалку для вытаскивания с огня горячего казана), из рук - кожемялку, из ног - костыли, из ребер - крышку для казана, внутренним жиром покрою аил, из желудка - «кожаный сосуд», из печени - подушку, из тонких кишок сделаю аркан и т. д. и т. п.

[Укачина 1984: 22].

\section{Заключение}

Сравнение с аналогичными описаниями на материале бурят и алтайцев показывает общее и особенное в калмыцкой традиции бытования загадок. К общим чертам можно отнести связь с зимним периодом (загадывание числовых загадок от одного до девяти как ускоренное проживание зимних «девятидневок», зимнего времени) и концепцию наказания проигравших, которая, несмотря на разные названия (у калмыков - осмеяние, у бурят и алтайцев - «продажа»), имеет одинаковую семантику выкупа частей тела проигравшего и трансформации их в различные предметы. Основное различие между указанными традициями составляют возрастные категории участников игры: у донских калмыков - это дети, молодежь, у селенгинских бурят - молодые супружеские пары, а у алтайцев, наоборот, - старшие по возрасту люди [Укачина 1984: 23].

Кроме того, И. И. Попов описывает эту игру как коллективную деятельность: «..как в загадках, так и отгадках партия рассматривается как корпорация, так что важен успех не отдельных личностей, а всей их совокупности» [ГАРО. Ф. 55. Оп. 1. Л. 2об.], что соотносится с данными М. А. Кастрена, согласно которым участники также делятся на группы. В культуре алтайцев, напротив, отсутствует обязательное условие «коллективности» игры: участниками могут выступать индивидуальные игроки [Укачина 1984: 21-22].

Труд И. И. Попова «Загадки донских калмыков», несомненно, представляет значительную научную ценность для исследователей как с точки зрения собранного фольклорного материала, так и с точки зрения зафиксированной ученым живой традиции бытования этого жанра среди калмыков. 


\section{Источники}

ГАРО - Государственный архив Ростовской области. Ф. 55. Оп. 1. Инв. № 13807.

\section{Литература}

Алексеева 2010 - Алексеева П. Э. Иван Попов - собиратель калмыцкого фольклора // О людях и времени: сб. ст. Элиста: КИГИ РАН, 2010. С. 77-79.

Бакаева 2016 - Бакаева Э. П. Об одной традиции монгольских народов // Этнографическое обозрение. 2016. № 6. С. 107-122.

Басангова 2009 - Басангова Т. Г. Детский фольклор калмыков. Элиста: КИГИ РАН, 2009. $72 \mathrm{c}$.

Бурыкин, Басангова 2009 - Бурыкин А. А., Басангова Т. Г. Типология калмыцкого фольклора. Элиста: НПП «Джангар», 2014. 212 с

Дыренкова 1940 - Дыренкова Н. П. Шорский фольклор. М.-Л.: Изд-во АН СССР, 1940. $448 \mathrm{c.}$

Жаргалова 2016 - Жаргалова Р. Д. Уникальное издание грамматики бурятского языка середины XIX века // Библиопанорама. 2016. № 2 (16). С. 58-61.

Калмыцкий эпос 1940 - Калмыцкий эпос «Джангар» / ред., вступ. ст., примеч. В. А. Закруткина. Ростов н/Д: Ростиздат, 1940. 272 с.

Лавонен 1977 - Лавонен Н. А. Карельская народная загадка. Ленинград: Наука, ЛО, 1977. $133 \mathrm{c}$.

\section{References}

Alekseeva P. E. Ivan Popov — a collector of Kalmyk folklore. In: Alekseeva P. E. About People and Time. Collected Articles. Elista: Kalmyk Humanities Research Institute of RAS, 2010. Pp. 77-79. (In Russ.)

Bakaeva E. P. On a Tradition of Mongolian Peoples. Etnograficheskoe obozrenie. 2016. Pp. 107-122. (In Russ.)

Basangova T. G. Kalmyk Childlore. Elista: Kalmyk Humanities Research Institute of RAS, 2009. 72 p. (In Russ. and Kalm.)

Burykin A. A., Basangova T. G. Typology of Kalmyk Folklore. Elista: Dzhangar, 2014. 212 p. (In Russ.)

Castren M. A. M. Alexander Castren's Versuch Einer Burjätischen Sprachlehre: Nebst Kurzem Wörterverzeichnis. St. Petersburg: Imperial Academy of Sciences, 1857. 244 p. (In Germ.)

Dyrenkova N. P. Shor Folklore. Moscow-Leningrad: USSR Academy of Sciences, 1940. 448 p. (In Russ.)

Kalmyk Epic of Jangar. V. Zakrutkina (ed., foreword, comments). Rostov-on-Don: Rostizdat, 1940. 272 p. (In Russ.)

Lavonen N. A. The Karelian Folk Riddle. Lenin-

\section{Sources}

State Archive of Rostov Oblast. Coll. 55. Cat. 1. File. no. 13807. (In Kalm. and Russ.)

Намкай Норбу 1997 - Намкай Норбу. Друнг, Дэу и Бон: традиции преданий, языка символов и бон в древнем Тибете. М.: Либрис, $1997.368 \mathrm{c}$

Селеева 2013 - Селеева Ц. Б. О калмыцких загадках: к проблеме сравнительно-типологической вариативности числовых загадок в фольклоре монгольских народов // Монголоведение. 2013. № 6. С. 71-93.

Убушиева 2017 - Убушиева Д. В. Кумулятивные образцы в коллекции сказок И. И. Попова // Вестник Калмыцкого института гуманитарных исследований РАН. 2017. № 3. C. 139-151. DOI: 10.22162/2075-7794-201731-3-139-151

Укачина 1984 - Укачина K. E. Алтайские народные загадки. Горно-Алтайск: Горно-Алтайск. отд. Алтайск. кн. изд-ва, 1984. 101 с.

Устиева 2010 - Устиева И. С. Жанровая специфика калмыцких народных загадок // Вестник Адыгейского государственного университета. Сер. 2: Филология и искусствоведение. 2010. № 3. С. 55-58.

Castren 1857 - Castren M. A. M. Alexander Castren's Versuch Einer Burjätischen Sprachlehre: Nebst Kurzem Wörterverzeichnis. St. Petersburg: Buchdruckerei der Kaiserlichen Akademie der Wissenschaften, 1857. $244 \mathrm{~s}$.

grad: Nauka, 1977. 133 p. (In Russ.)

Namkhai Norbu. Drung, Deu, and Bön: Narrations, Symbolic Languages, and the Bön Traditions in Ancient Tibet. Moscow: Libris, 1997. 368 p. (In Russ.)

Seleeva Ts. B. Kalmyk riddles revisited: comparative typological variations of numerical riddles in Mongolic folklore traditions. In: Mongolian Studies. Vol. 6. Elista: Kalmyk Humanities Research Institute of RAS, 2013. Pp. 71-93. (In Russ.)

Ubushieva D. V. Cumulative fairy tales from I. I. Popov's collection. Bulletin of the Kalmyk Institute for Humanities of the RAS (Oriental Studies). 2017. No. 3. Pp. 139-151. (In Russ.) DOI: $10.22162 / 2075-7794-2017-31-3-139-151$

Ukachina K. E. Altaian Folk Riddles. Gorno-Altaysk: Altaian Book Publ., 1984. 101 p. (In Russ.)

Ustieva I. S. Genre specifics of Kalmyk folk riddles. The Bulletin of the Adyghe State University, the Series 'Philology and the Arts'. 2010. No. 3. Pp. 55-58. (In Russ.)

Zhargalova R. D. A unique mid- $19^{\text {th }}$-century essay on Buryat grammar. Bibliopanorama. 2016. No. 2 (16). Pp. 58-61. (In Russ.) 


\section{Приложение. Факсимиле предисловия И. И. Попова}

к труду «Загадки донских калмыков»

[Appendix. Facsimile of I. Popov's Foreword to 'Riddles of the Don Kalmyks']

\section{II $P$ II}

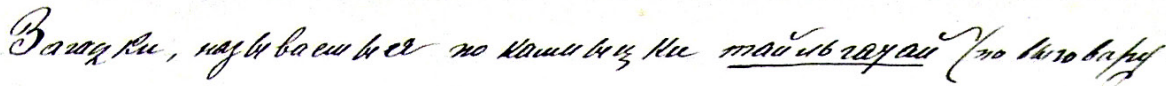

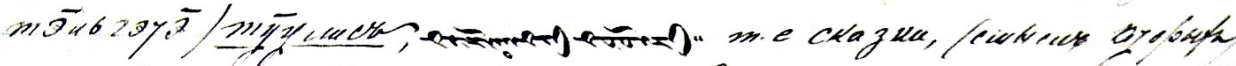

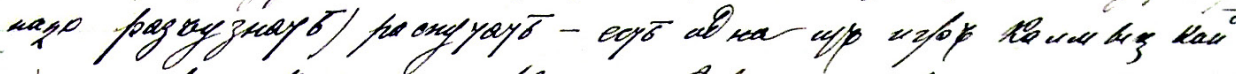

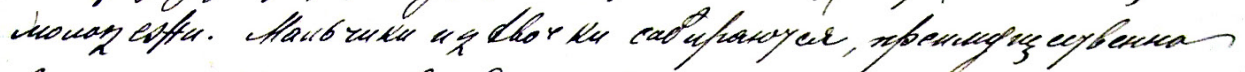

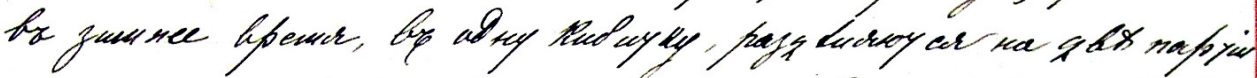

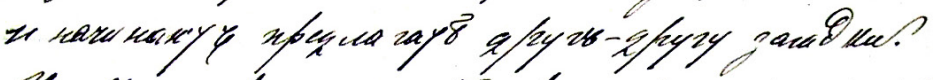

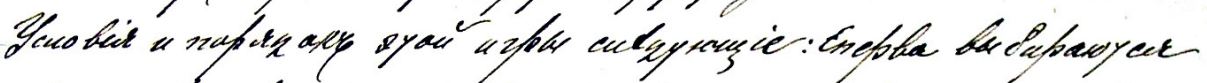

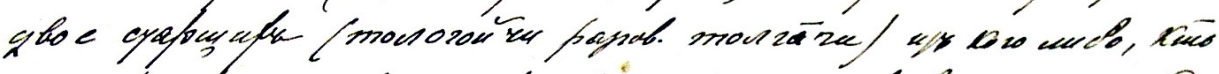

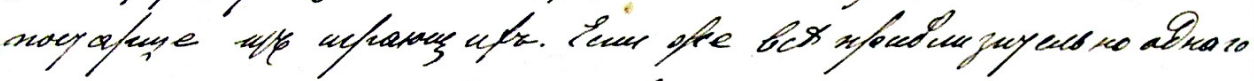

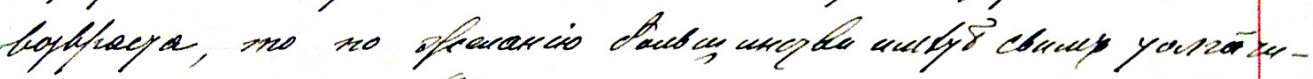

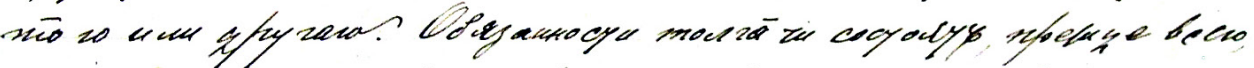

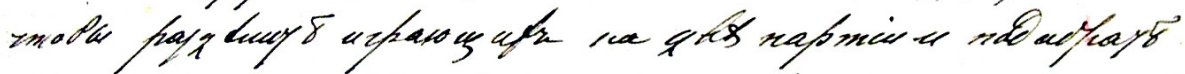

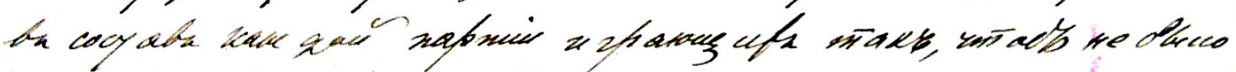

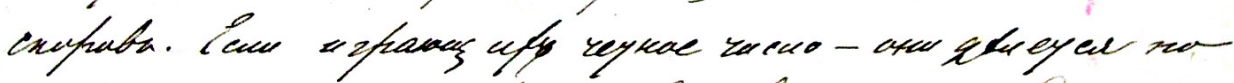

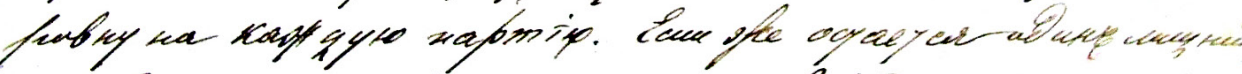

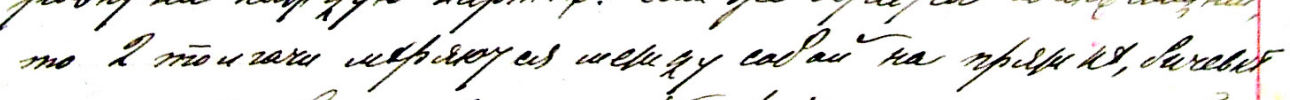

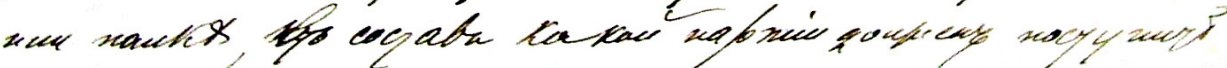

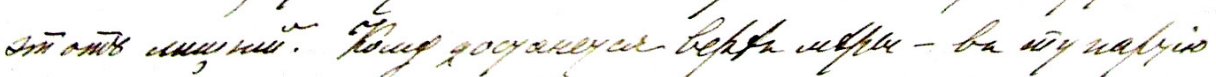

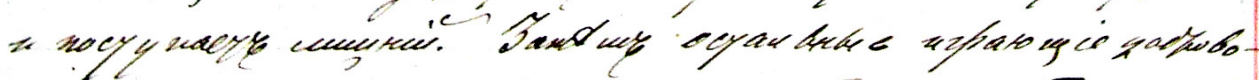

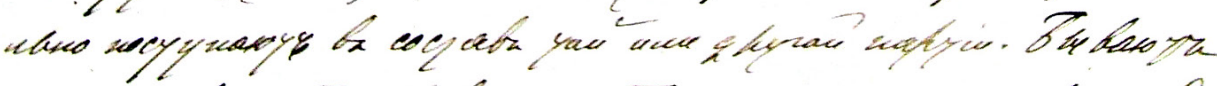

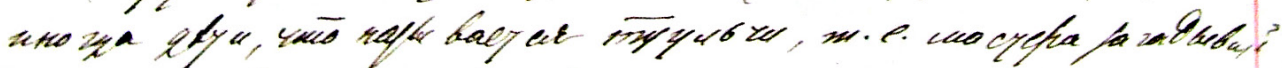

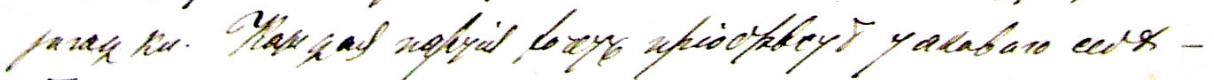

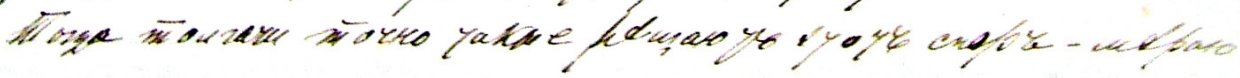




\section{0}

$\pi$

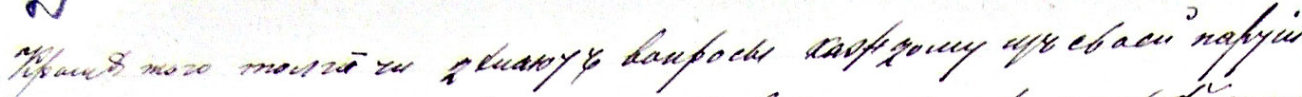

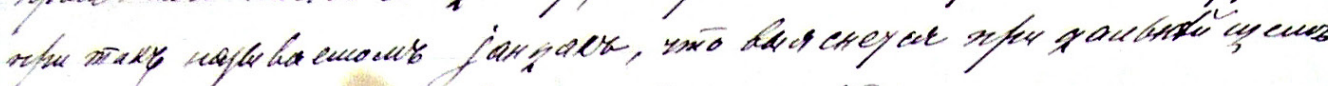

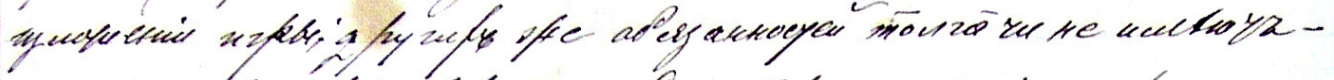

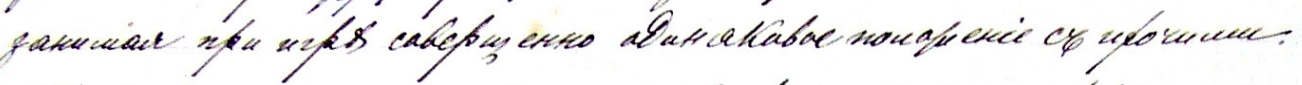

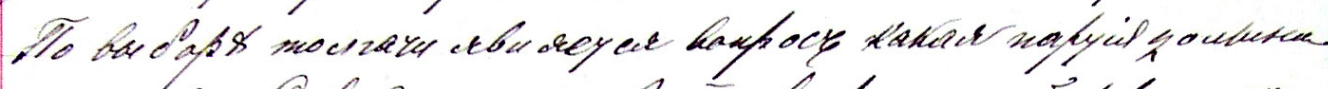

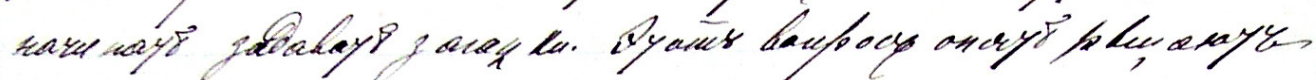

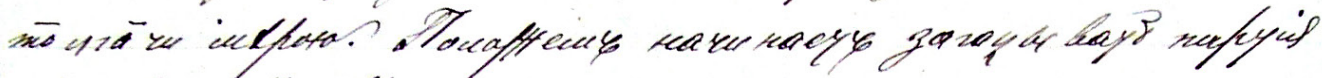

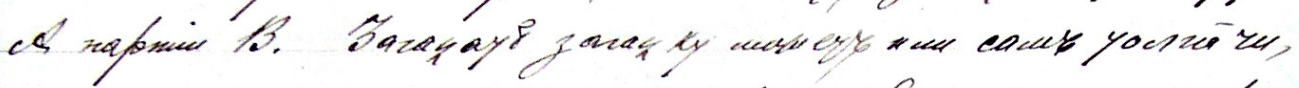

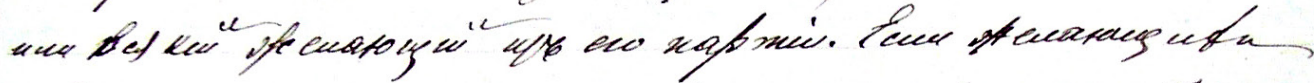

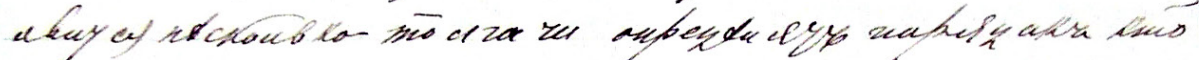

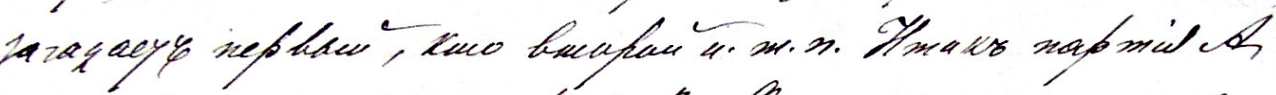

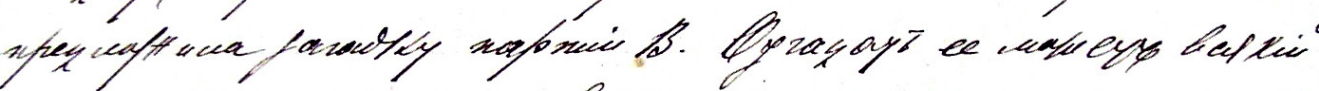

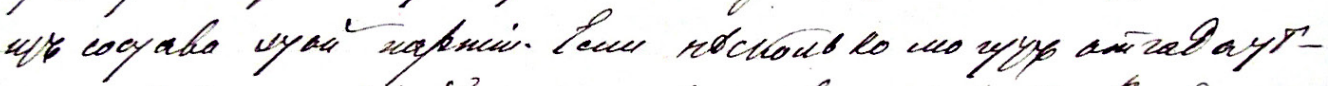

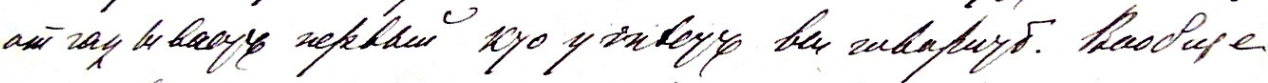

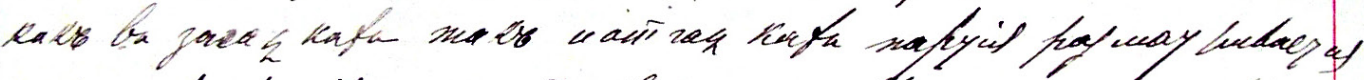

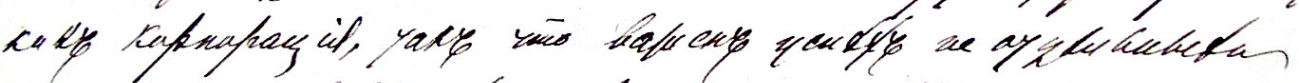

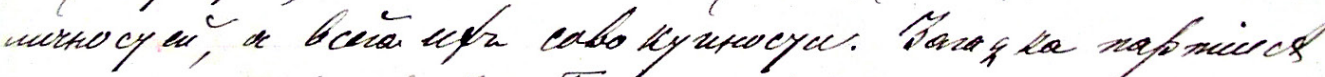

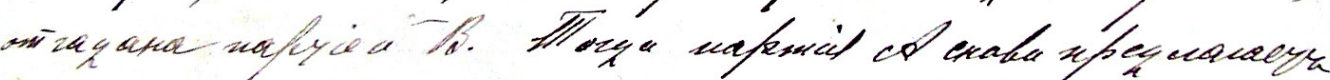

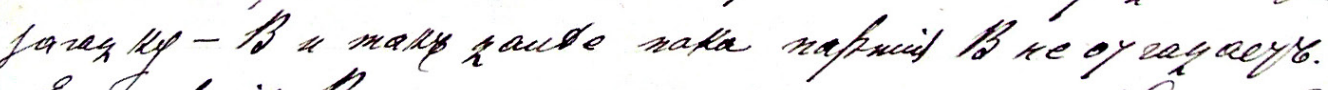

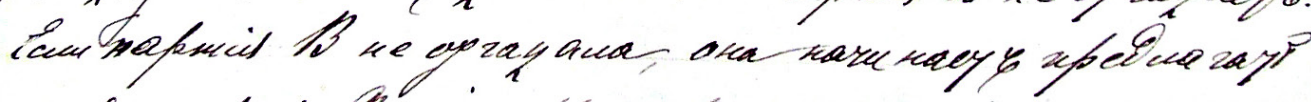

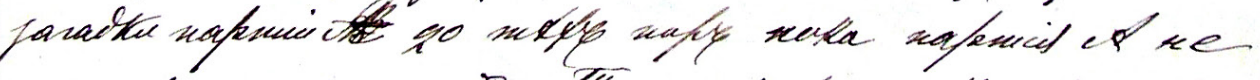

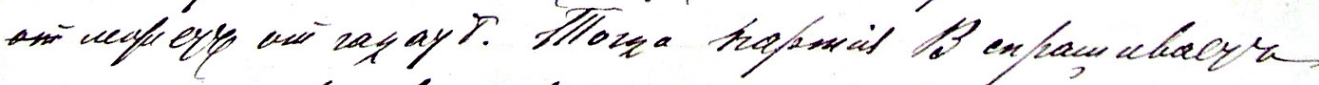

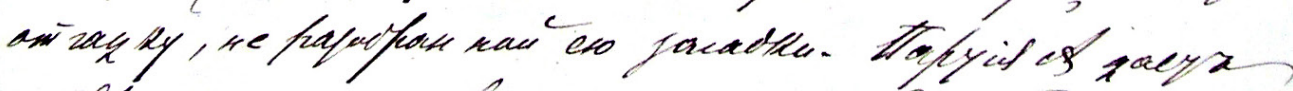

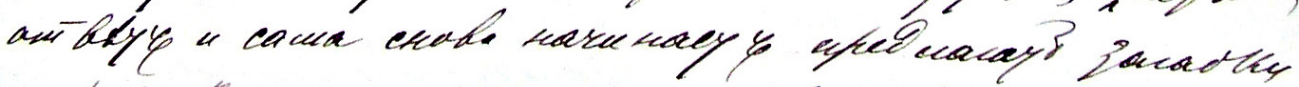

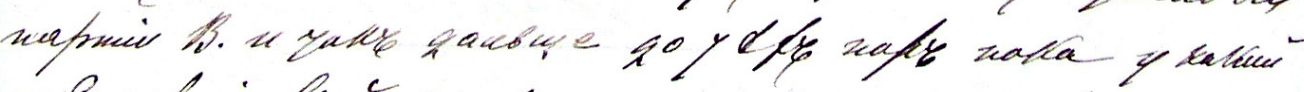

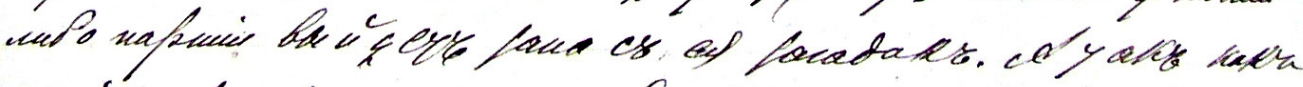

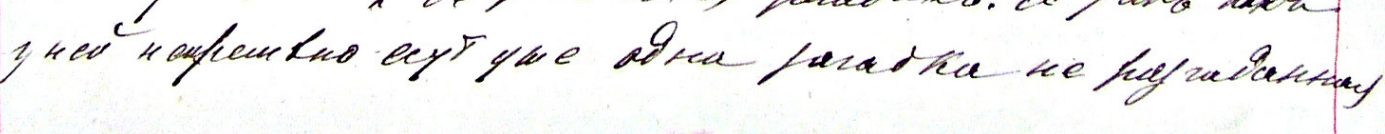


III.

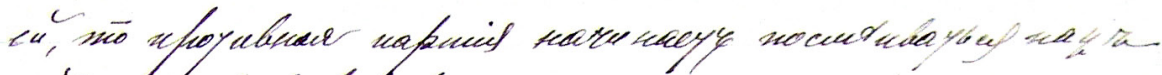

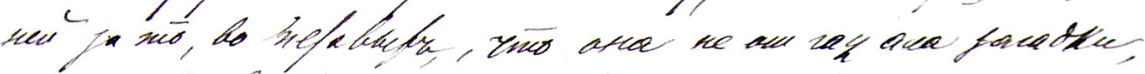

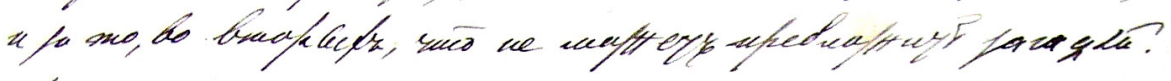

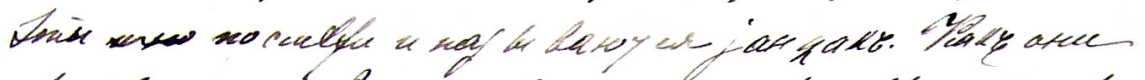

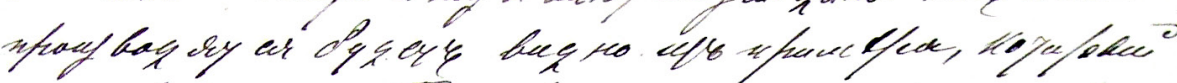

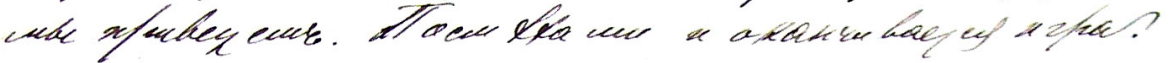

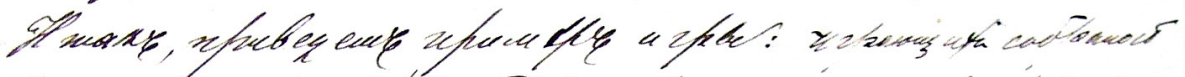

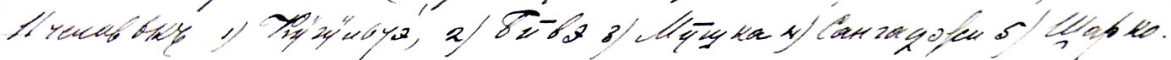



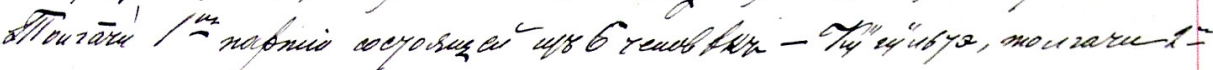

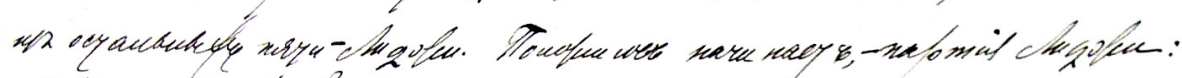

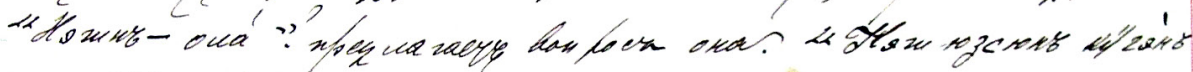

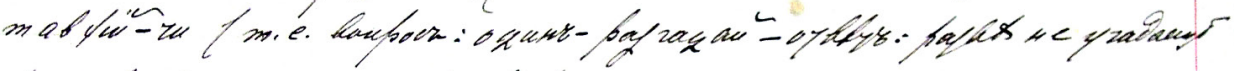

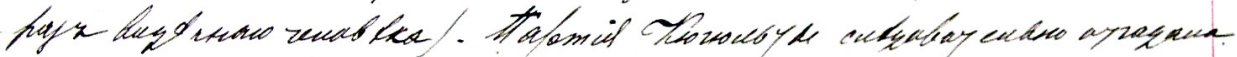



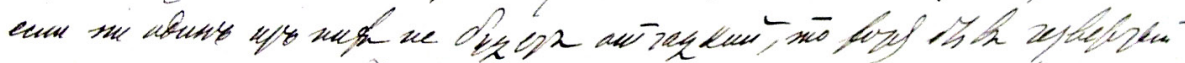

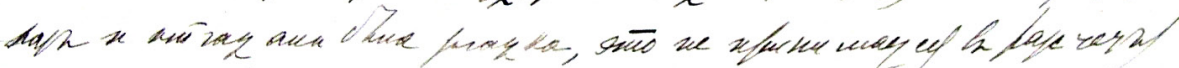

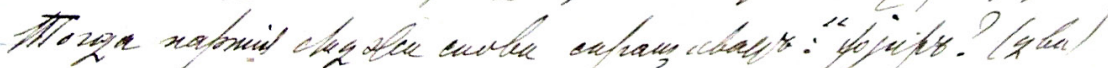

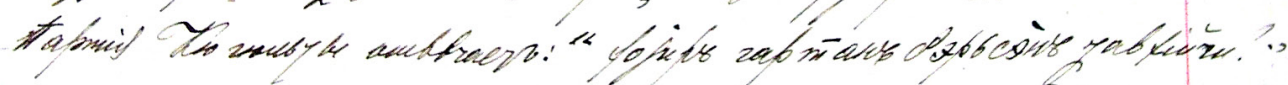

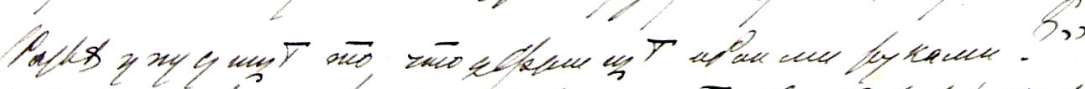

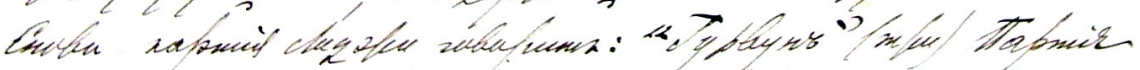

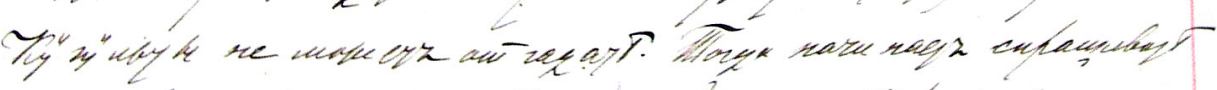

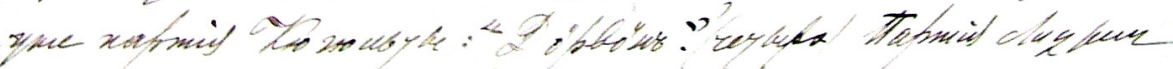

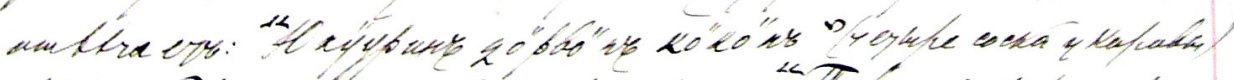



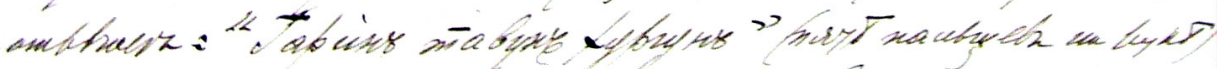

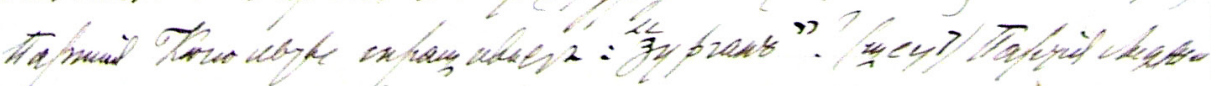




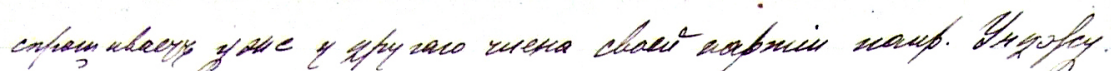

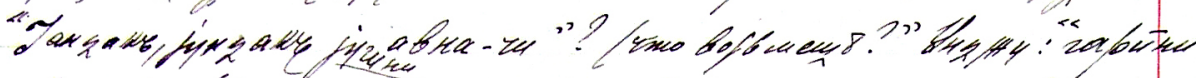

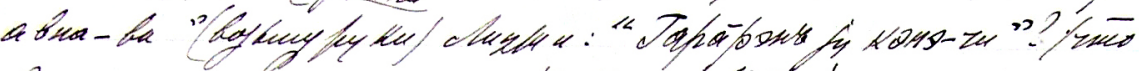



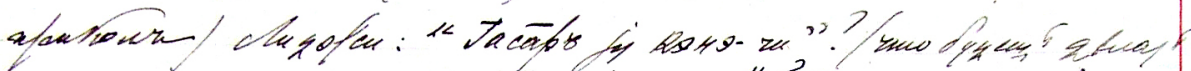

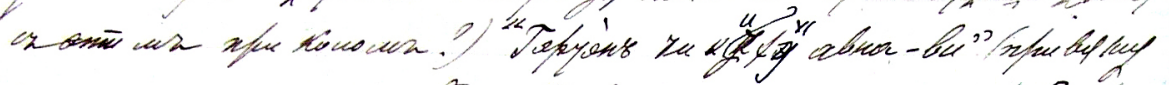

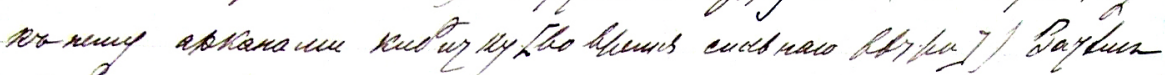

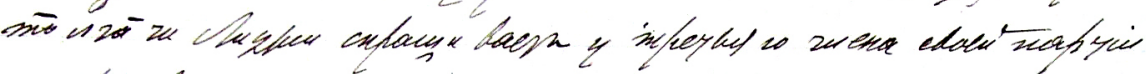

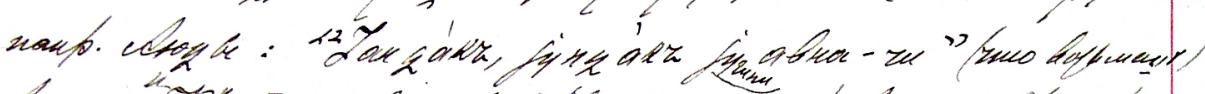





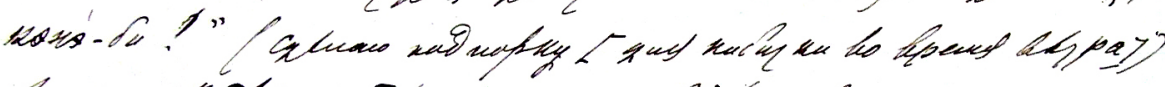

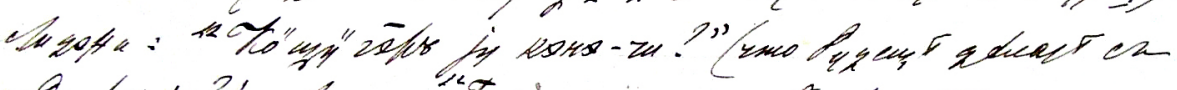

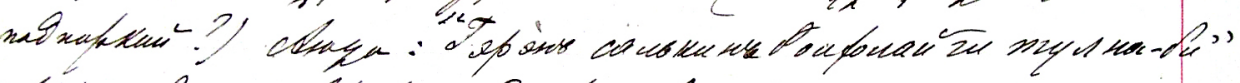

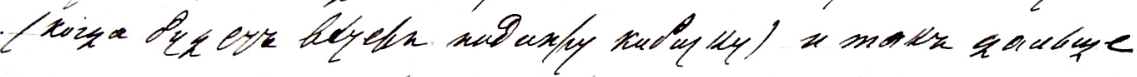

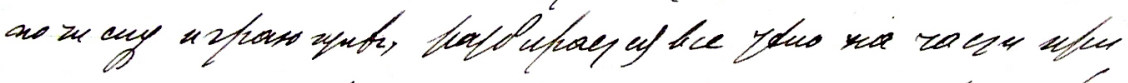

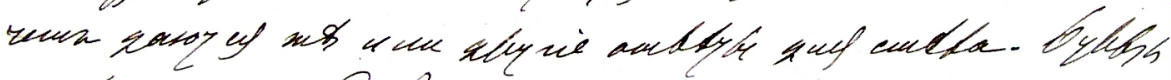

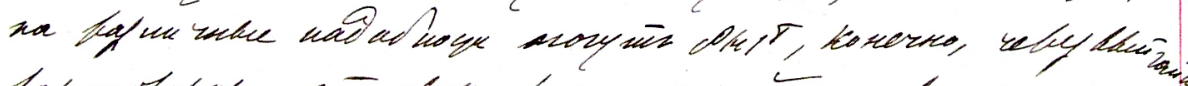

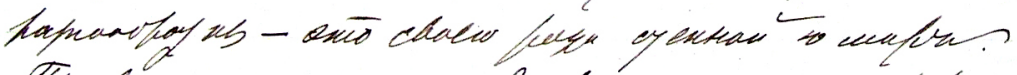

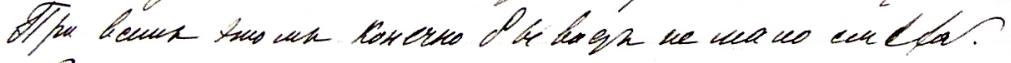

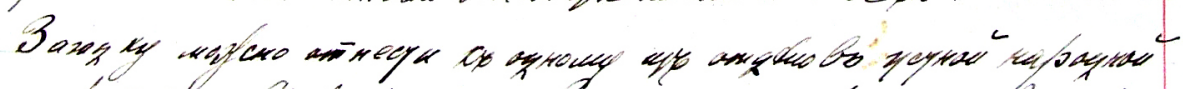

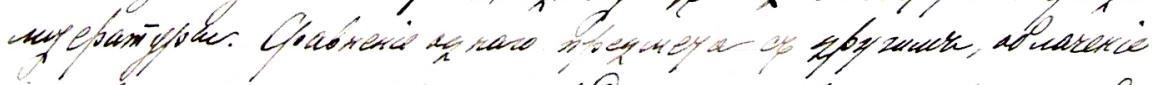

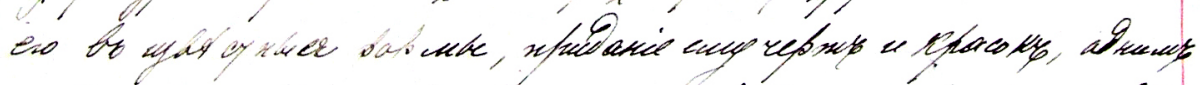



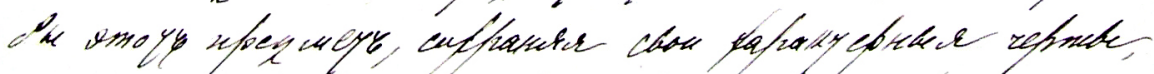

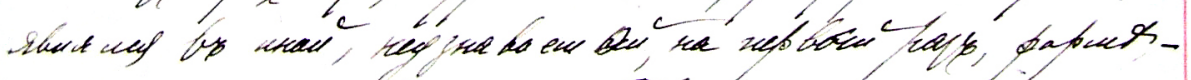

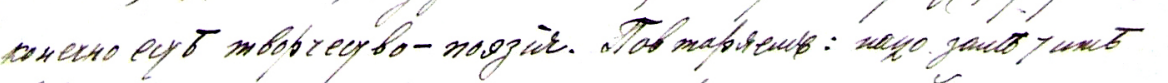

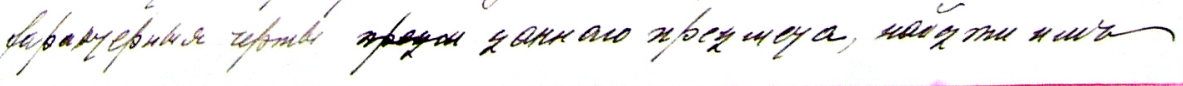




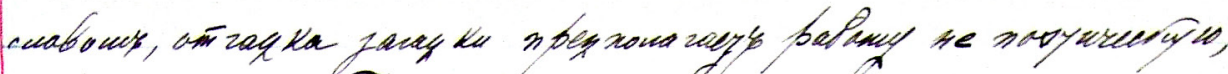



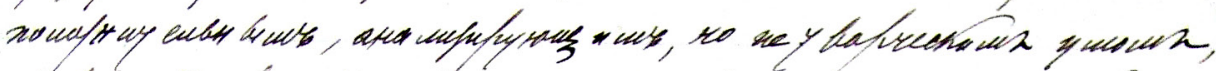

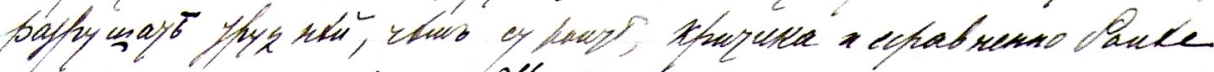

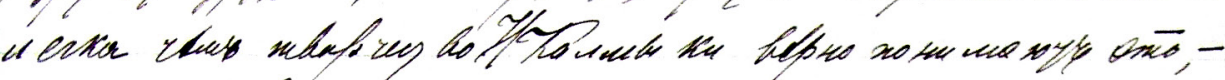

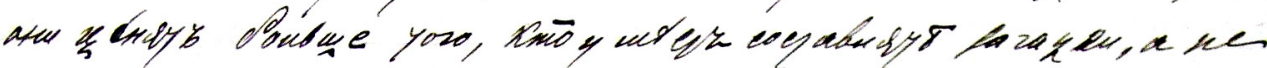

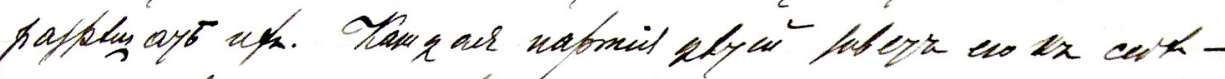

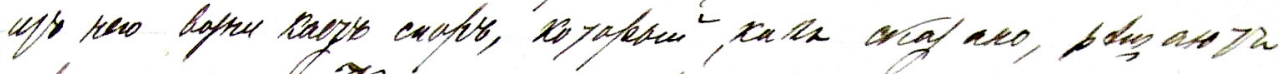

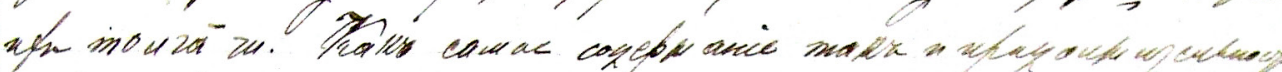

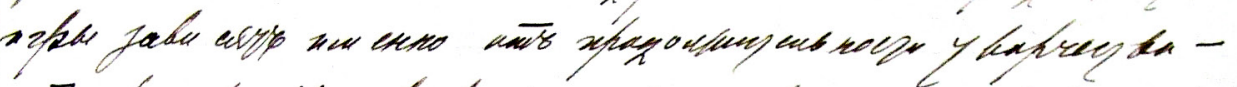

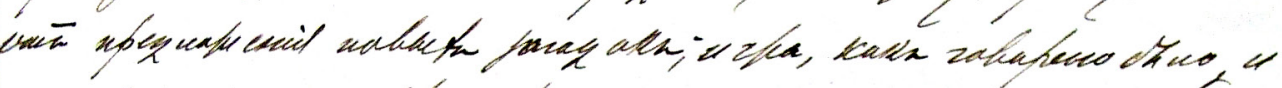

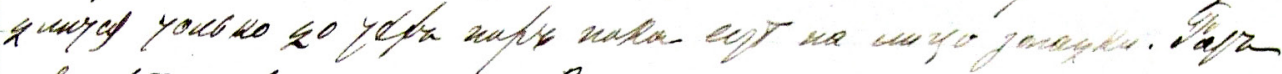



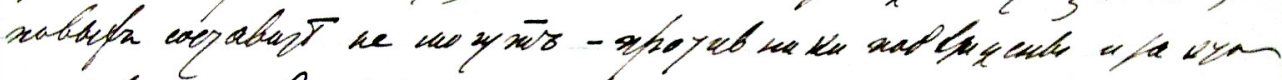

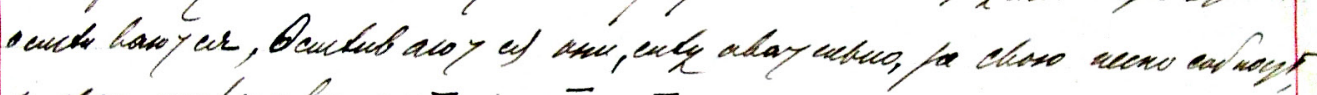

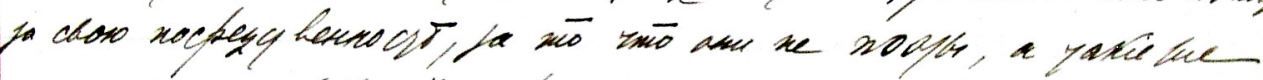

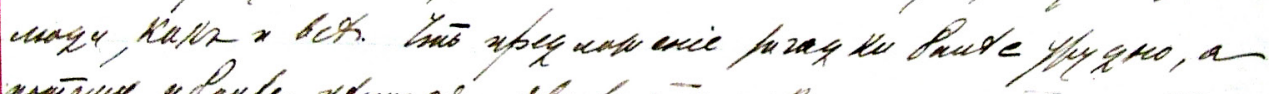

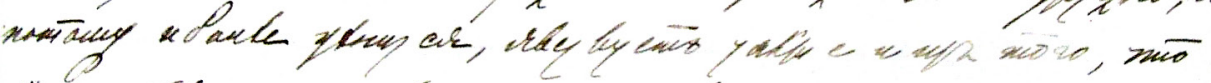

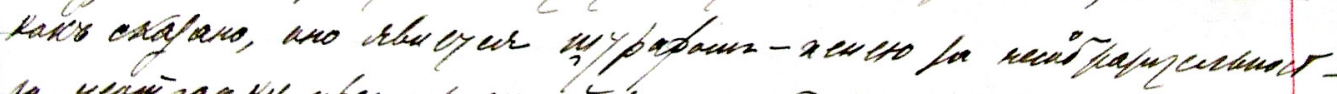

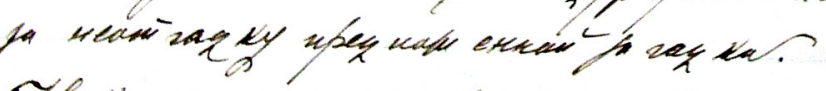

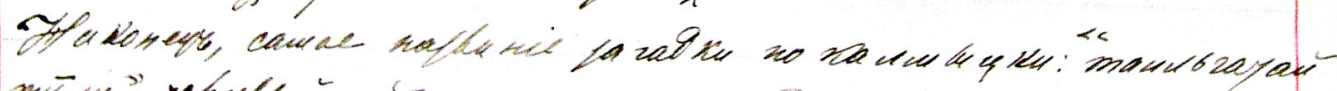

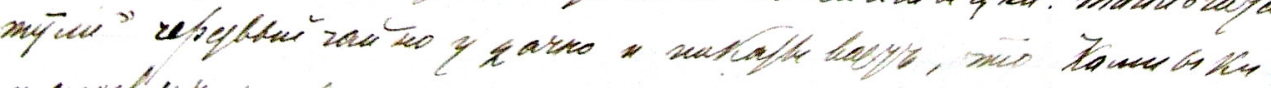

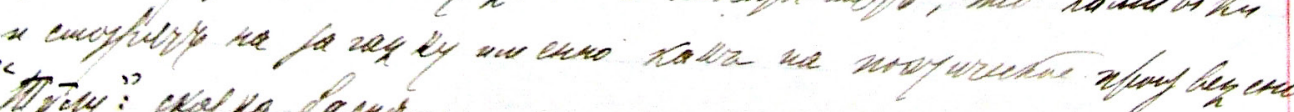
"How" sear wa, dowd.

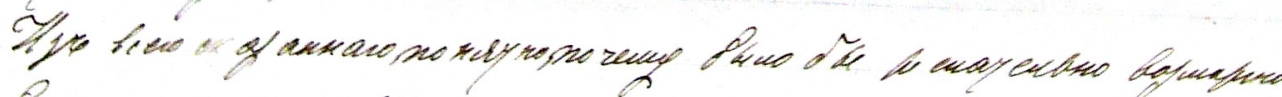

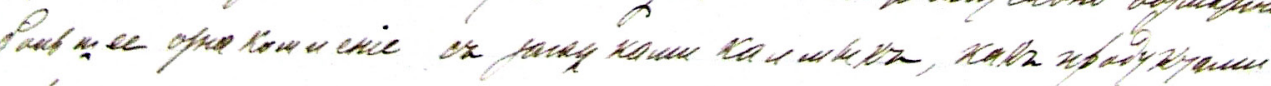




X.



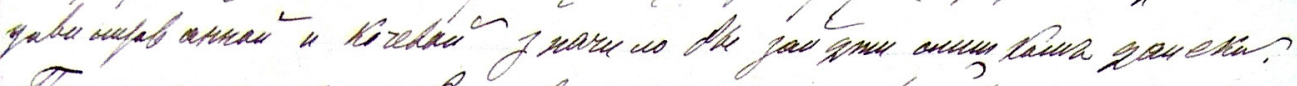

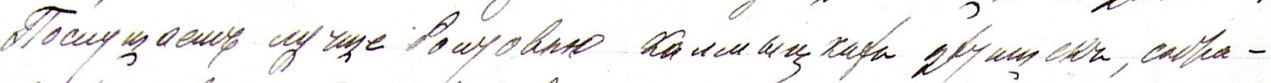

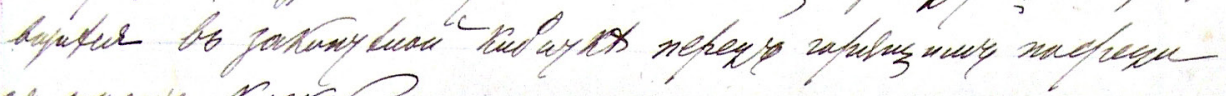

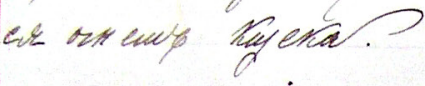

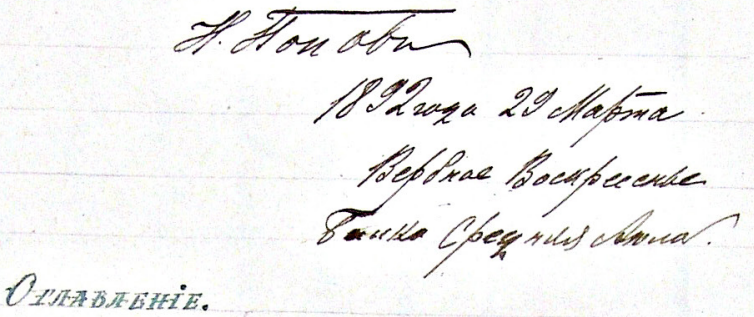

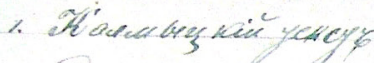

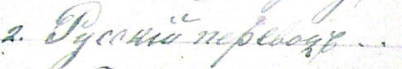

3. Alsucurtiancis. 